\title{
Gender Equality Capacity of Administrative Council Members in a State University and Local Universities and Colleges
}

\author{
Maria Teresa M. Rodriguez ${ }^{1}$, Consorcia S. Tan ${ }^{1}$, Lerma P. Buenvinida ${ }^{1}$, Lustina P. Lapie ${ }^{2}$ \\ ${ }^{1}$ College of Teacher Education, ${ }^{2}$ College of Fisheries \\ Laguna State Polytechnic University-Los Banos Campus \\ Los Banos, Laguna, Philippines
}

\begin{abstract}
The study determines the academic leadership capabilities, administrative creativity and gender equality capacities of administrative council members of a state university and local colleges in the province of Laguna, Philippines. The respondents were members of the university/college administrative council. In terms of administrative functions, many are chairpersons or coordinators while some are in the higher position like campus directors and vice-presidents. Findings reveal

that there is a positive and significant relationship between the following subscales of academic leadership and gender equality capacity: cognitive capability and programmes, change - oriented capability and programmes, skills and processes; role-specific and programmes and operations Further, it was observed that leadership performance is positively and highly significantly related to all subscales of gender equality capacity. Meanwhile, there is a highly significant relationship between respondent's administrative creativity and gender equality in terms of skills and processes. This implies that the more creative the administrative council members, the more confident in their gender equality capacity in terms of skills and processes. Majority of the respondents experienced training or orientation on gender issue and have taken gender related courses in the last two years. However, most of them are not satisfied with the training. Hence it is recommended that the local colleges and university need to conduct seminars and trainings to enhance the awareness of the officials and other constituents on gender sensitivity.
\end{abstract}

Keywords: gender equality capacity, academic leadership, administrative council members, administrative functions, personal capability, cognitive capability, gender issue

\section{Introduction}

According to Eliadis (2018), gender equality is the equal rights, responsibilities and opportunities for both women and men. This means that "equality of women's and men's rights, responsibilities and opportunities will not depend on whether they are born male or female". Gender equality emphasizes that the interests, needs and priorities of both women and men; their diversified groups are considered and recognized. It is notable that gender equality is not always women's issue but should concern and fully engage both men and women. Hence, equality between women and men is considered both as a human rights issue and an indicator of sustainable people-centered development.

Gender equality capacity assessment deals with assessing the understanding, knowledge, and skills that a given organization and individuals have on gender equality and the empowerment of women, and on the organization's gender architecture and gender policy. Capacity assessment refers to the process through which the information is gathered and analyzed and to the results of this analysis. These results are conveyed in a report that outlines the ways forward for a training or capacity development strategy or action plan (UN Women Training Centre, 2014). 
To assess the capacity of individuals some commonly used tools are questionnaires and surveys, individual tests, focus groups, and interviews. Capacity assessment at an organizational level evaluates what policies, strategies and procedures are in place to ensure that gender equality and the empowerment of women can adequately be included in the agency's mandate. The Participatory Gender Audit, a methodology developed by the ILO, is a systematic, participatory and gender-sensitive methodology for analyzing how gender is mainstreamed within an organization or a part of it (UN Women Training Centre, May 2014).

This study was limited only in determining the gender equality capacity of the administrative council members on their academic leadership and administrative creativity in a state and local universities and colleges in the province of Laguna, Philippines. The results of the study provided a springboard data that could help the organizations or concerned group of people to come up with different intervention programs concerning gender equality; a guide for the school administration in drafting school strategic plan with the inclusion of gender sensitivity on the implementation of programs and projects which employ equal treatment to the faculty and staff with their benefits, rights, opportunities, value, situation and outcome. They could realize the importance of equality among their subordinates pertaining their capabilities regardless of their sexes that they could perform well with the same acquired knowledge and skills. The faculty and staff could be given the opportunity to develop their capacities in delivering their particular task or profession by allowing them to participate in decision-making and be part of the management team especially those female employees who they think have the knowledge and skills similar to the abilities of male leaders. They can gain equal rights, privilege, benefits, and value their contribution to the development of their respective institution. The study pursued if there is a significant relationship between gender equality capacities and the academic leadership capability of an administrative council member and if there is a significant relationship between gender equality capacities and the administrative creativity of an administrative council member.

Beneria, L., Berik, G., Floro, M. (2016) shared that the gendering of individuals happens through the process of socialization, in which individuals who are born female and male become women and men in the context of family, schools, communities, workplaces, and under the dictates of social norms and the risk of social, sometimes legal, sanctions. The process attributed much conformity to norms as active creation of gendered behaviors. This details of gender as a product of individual agency offers the possibility of multiple gender identities that defy the gender (man-woman) binary. The individuals tend to "do gender" is synonymous to live up to the ideals appropriate for their gender in a given social context.

While there is an opportunity for various forms of conformity, the rewards for gender conformity often direct individuals to "do gender," that is, to live up to the ideals appropriate for their gender in a given social context. Evidence supporting the doing gender hypothesis is seen in situations where women or men appear to be deviating from gender norms (Bittman et al., 2003; Sevilla-Sanz et al., 2010; Baxter and Hewitt, 2013).

\section{Literature Review}

As cited in Gakiya, et al. (2016), "gender equality is not only a fundamental human right, but a necessary foundation for a peaceful, prosperous and sustainable world" As stated on the UN Sustainable Development Goals, 2012, it is therefore essential to find a way to build bridges across political, economic, and cultural divides, to help these societies adjust to these changes and resolve emerging conflicts. Diplomacy in the 20th century was focused primarily on "power sharing," but the 21 st century paradigm must address emerging human and environmental challenges and requires to create policies and actions that center on "responsibility sharing" (Anderlini, 2015).

Gender equality ability evaluation is a way of assessing the awareness, expertise and skills that a given organization and individuals have on gender equality and women's empowerment, and on the gender structures and gender policy of the organization. Capacity evaluation refers to the method by which the information is obtained and evaluated, and to the outcomes of this analysis. Such results are expressed in a study detailing ways forward for a policy or action plan for training or capability growth. 
In determining individual ability, attention is paid to the awareness, skills, and attitudes that each person has about gender equality and women's empowerment and their incorporation into their day-to-day work. The information that will be collected includes how much they know and understand specific concepts (e.g. gender equality, empowerment of women, etc.), policies (e.g. organizational gender strategy, gender mainstreaming strategy) and procedures (e.g. how gender equality should be reflected in procurement or recruitment processes) and how they are capable of implementing all these and these processes.

To assess the capacity of individuals, some commonly used tools are questionnaires and surveys, individual tests, focus groups, and interviews. Capacity assessment at an organizational level evaluates what policies, strategies and procedures are in place to ensure that gender equality and the empowerment of women can adequately be included in the agency's mandate. The Participatory Gender Audit, a methodology developed by the ILO, is a systematic, participatory and gender-sensitive methodology for analyzing how gender is mainstreamed within an organization or a part of it (UN Women Training Centre, May 2014).

According to the study of $\mathrm{Wu}$ and Cheng (2016), there is a long tradition of economic research into gender equality. Traditionally, people agree that higher equity between female and male workers within the same company contributes to a more harmonious and productive environment; therefore, all workers would be motivated to contribute substantially to and support the growth of the firm.

In the 21 st century, leadership capabilities are inevitably crucial for any future leader who meets intense challenges and wishes to lead effectively. In an education circle, academic leaders need helpful and flourishing practices, not just in familiar contexts, but in unfamiliar, complex, and dynamic circumstances as well. The incredible growth of a country depends significantly on the role of the teachers since the quality of the nation's manpower depends on education. Academic leaders are not only referring to administrators, presidents, head teachers, superintendents and deans, but also to school teachers and their leadership skills. This means that for any role in an academic institution, academic leadership is very important. This is not just about senior management positions (Jacqueline \& Rungrojngarmcharoen, 2014). Successful leaders also use photos, metaphors and stories to win over people according to Ancona and Bresman (2018).

In the study of Ibtisam Khalid, Yahia Salama (2018), the fabric of organizational values and relationships composed by the organizational culture represent the most important component of the good organizational environment which qualifies the workers to develop the performance through accomplishing the administrative creativity, which is considered one of the most important objectives that organizations sought to accomplish in today's world. It is also cited in her study that according to Bruise (2016) today's organizations lives in changing and complicated circumstances, making their need of administrative creativity an urgent one, as the managers who manage today's organizations have to be keen to grow and develop workers' capabilities of contributing to problem solving and participating in decision making and generating ideas.

The administrative creativity includes a set of resources based on the human element and knowledge. Being ordered and organized in steps and phases of activities which are being approved to achieve creations in the form of a product or a service or a system (Gapar \& Mabic, 2014). Shagoura (2012) as cited in Salama (2018) added that the renovation is considered the essence of the administrative creativity of any organization, making it an urgent need. It contributes in improving the capabilities and generation of ideas. It is coping with the modern technical developments, problem solving and participating in making the proper decisions in the proper time. It has become clear that today's organizations - due to the fast base international and domestic changes around them, and due to the ambiguity of that surrounding environment dictating the unpredictability of the future changes facing the organizations - they have to strive to identify their organizational culture and insure the compatibility of the components of that culture with the beliefs, values, orientations of the requirements of the times like knowledge and flexibility and development. Hence, strengthening the administrative creativity through the suitable organizational atmosphere and providing the reasons and means which enable its employees to achieve that creativity (European Scientific Journal February 2018 edition Vol.14, No.4 ISSN: 1857 - 7881 (Print) e - ISSN 1857- 7431 147). 


\section{Methodology}

The study employed descriptive- correlational research design and the respondents were the administrative council members of one state university and 4 local universities and colleges in the province of Laguna, Philippines. The administrative council members are the vice presidents, campus directors, directors, college deans, associate deans, department heads and chairpersons. The total number of respondents in this study is 153 which were randomly selected from the total population. Slovin's Formula was used to calculate an appropriate sample size from a population of 253 with 95 percent confidence level and 5 percent margin of error. The study utilized survey questionnaire to gather data. The first part of the questionnaire elicited information regarding the profile of the respondents that consist of age, sex, year of service, educational attainment, and administrative council position. The second part pertains to the academic leadership capability composed measured in terms of personal capability, interpersonal, cognitive capability, changeoriented, generic competency, role-specific competency and leadership performance. There are 146 questions in the survey questionnaire adopted from the research study of Scott Caotes Anderson (2008) entitled" Academic Leadership Capability Framework". The Likert Scale used to measure and interpret the level of capability with corresponding scores are the following: High Importance (4); Medium Importance (3); Low Importance (2); and No Importance (1).

The third part deals with the administrative creativity with 15 questions. The Likert Scale to measure and interpret the extent of creativity are distributed as: Great Extent (4); Some Extent (3); Slight Extent (2); and Not at all (1). The fourth part is the gender equality capacity with 25 questions. The first two questions are answered with yes or no. The following Likert Scales used and interpreted measured the level of knowledge of gender equality and how they included gender equality in programme and operations: Very relevant (4); Relevant to a limited degree (3); Not relevant at all (2); Not applicable (1), and the other Likert used are: I am confident enough to lead work on this (4); I am confident enough to use this to my everyday work (3); I know about this (2); and I don't know about this (1). This gender equality survey was adopted and based on the" Gender Equality Capacity Assessment Tool" for assessment of capacity in promoting gender equality and the empowerment of women for the UN System and other partners.

To determine the extent of the importance of academic leadership capability, administrative creativity, and gender equality capability, weighted mean and standard deviation were used. Chi square test and Pearson $r$ were employed to determine the significant association and relationship between the two variables.

\section{Results and Discussions \\ Result}

Table 1 shows the academic leadership of a university/college administrative council member in terms of personal capability, interpersonal capability, cognitive capability, change-oriented capability, generic competency, role-specific and leadership performance.

Table 1. Academic leadership of a university/college administrative council member

\begin{tabular}{|l|l|l|c|}
\hline Indicators & Mean & SD & Descriptive Interpretation \\
\hline Personal Capability & 3.73 & 0.25 & High Importance \\
\hline Interpersonal Capability & 3.75 & 0.30 & High Importance \\
\hline Cognitive Capability & 3.73 & 0.29 & High Importance \\
\hline Change-Oriented Capability & 3.67 & 0.31 & High Importance \\
\hline Generic Competency & 3.76 & 0.32 & High Importance \\
\hline Role-Specific & 3.74 & 0.57 & High Importance \\
\hline Leadership Performance & 3.68 & 0.39 & High Importance \\
\hline Composite & 3.72 & 0.35 & High Importance \\
\hline
\end{tabular}

Legend: $3.50-4.00=$ High Importance; $2.50-3.49=$ Medium Importance; $1.50-2.49=$ Low Importance 
It could be seen from Table 1 that all the indicators of academic leadership were considered by the respondents to be of high importance with means higher than 3.50 with change -oriented capability obtaining the slightly lowest mean of 3.67 (SD - 0.31). This means that the capability of a leader who tries to promote exploration of new and better ways of doing things, or trying to uncover hidden potential in people, things, or situations is not that much compared to other indicators of academic leadership

Table 2 shows the administrative creativity of a university/college administrative council member.

Table 2. Administrative creativity of a university/college administrative council member

\begin{tabular}{|c|c|c|c|}
\hline Indicative Statement & Mean & SD & $\begin{array}{l}\text { Descriptive } \\
\text { Interpretation }\end{array}$ \\
\hline I suggest new ways to achieve goals or objectives. & 3.63 & 0.50 & Great Extent \\
\hline $\begin{array}{l}\text { I come up with new and practical ideas to improve } \\
\text { performance. }\end{array}$ & 3.69 & 0.48 & Great Extent \\
\hline $\begin{array}{l}\text { I search out new technologies, processes, techniques, } \\
\text { and/or product idea. }\end{array}$ & 3.57 & 0.57 & Great Extent \\
\hline I suggest new ways to increase quality. & 3.73 & 0.46 & Great Extent \\
\hline I consider myself a good source of creative ideas. & 3.51 & 0.54 & Great Extent \\
\hline I am not afraid to take risks. & 3.51 & 0.55 & Great Extent \\
\hline I promote and champions ideas to others. & 3.58 & 0.57 & Great Extent \\
\hline $\begin{array}{l}\text { I exhibit creativity on the job when given the } \\
\text { opportunities. }\end{array}$ & 3.68 & 0.48 & Great Extent \\
\hline $\begin{array}{l}\text { I develop adequate plans and schedules for the } \\
\text { implantation of new ideas. }\end{array}$ & 3.59 & 0.53 & Great Extent \\
\hline I often have new and innovative ideas. & 3.52 & 0.54 & Great Extent \\
\hline I come up with creative solutions to problems. & 3.60 & 0.49 & Great Extent \\
\hline I often have a fresh approach to problems. & 3.54 & 0.51 & Great Extent \\
\hline I suggest new ways of performing work tasks. & 3.63 & 0.54 & Great Extent \\
\hline $\begin{array}{l}\text { I am self-assured about my capabilities to perform my } \\
\text { work. }\end{array}$ & 3.65 & 0.48 & Great Extent \\
\hline I mastered the skills necessary to my job. & 3.69 & 0.48 & Great Extent \\
\hline Composite & 3.61 & 0.36 & Great Extent \\
\hline
\end{tabular}

Legend: $3.50-4.00=$ Great Extent; $2.50-3.49=$ Some Extent; $1.50-2.49=$ Slight Extent; $1.00-1.49$ = Not at all

Indicative statements 5,6 and 10 have means ranging from 3.51-3.52 which implied that administrative council members have not introduced much greater and innovative ideas in the operations of their offices.

Table 3. Gender equality capacity of a university or college administrative council member in terms of training or orientation

\begin{tabular}{|l|l|l|l|l|}
\hline Indicative Statement & \multicolumn{2}{l|}{ Yes } & No \\
\cline { 2 - 5 } & $\mathrm{f}$ & $\%$ & $\mathrm{~F}$ & $\%$ \\
\hline $\begin{array}{l}\text { Have you received an introductory training or } \\
\text { orientation on gender issue? }\end{array}$ & 119 & 77.8 & 34 & 22.2 \\
\hline
\end{tabular}




\begin{tabular}{|l|l|l|l|l|}
\hline $\begin{array}{l}\text { Have you had taken gender related training or } \\
\text { courses in the last two years? }\end{array}$ & 93 & 60.8 & 60 & 39.2 \\
\hline Are you satisfied with the course/ training? & 73 & 47.7 & 80 & 52.3 \\
\hline
\end{tabular}

Table 3 reveals that majority of the respondents experienced training or orientation on gender issue $(77.8 \%)$ and have taken gender related courses in the last two years $(60.8 \%)$. However, only $47.7 \%$ are satisfied with the training.

Table 4. Gender equality capacity of a university or college administrative council member in terms of programs and operations

\begin{tabular}{|c|c|c|c|}
\hline Indicative Statement & Mean & $\mathrm{SD}$ & $\begin{array}{l}\text { Descriptive } \\
\text { Interpretation }\end{array}$ \\
\hline \multicolumn{4}{|l|}{ A. Operations } \\
\hline $\begin{array}{l}\text { How relevant do gender concerns influence your } \\
\text { everyday work? }\end{array}$ & 3.37 & 0.73 & $\begin{array}{l}\text { Moderately } \\
\text { Relevant }\end{array}$ \\
\hline $\begin{array}{l}\text { How relevant is gender on the mandate of your } \\
\text { institution/organization? }\end{array}$ & 3.49 & 0.67 & $\begin{array}{l}\text { Moderately } \\
\text { Relevant }\end{array}$ \\
\hline $\begin{array}{l}\text { Is gender relevant to the work of your } \\
\text { department/unit? }\end{array}$ & 3.36 & 0.79 & $\begin{array}{l}\text { Moderately } \\
\text { Relevant }\end{array}$ \\
\hline $\begin{array}{l}\text { How relevant is the trainings on gender equality in } \\
\text { improving your work? }\end{array}$ & 3.37 & 0.74 & $\begin{array}{l}\text { Moderately } \\
\text { Relevant }\end{array}$ \\
\hline $\begin{array}{l}\text { How important are the tools and/or sources of } \\
\text { information do you use to support your knowledge of } \\
\text { and/or the inclusion of gender equality issues in your } \\
\text { work? }\end{array}$ & 3.42 & 0.68 & $\begin{array}{l}\text { Moderately } \\
\text { Relevant }\end{array}$ \\
\hline Subscale & 3.40 & 0.63 & $\begin{array}{l}\text { Moderately } \\
\text { Relevant }\end{array}$ \\
\hline \multicolumn{4}{|l|}{ Programmes } \\
\hline $\begin{array}{l}\text { How relevant to your work the familiarization of the } \\
\text { International Conventions on Gender Equality and the } \\
\text { Empowerment of Women? }\end{array}$ & 3.37 & 0.69 & $\begin{array}{l}\text { Moderately } \\
\text { Relevant }\end{array}$ \\
\hline $\begin{array}{l}\text { How about the difference between gender } \\
\text { mainstreaming and equal representation of women? }\end{array}$ & 3.41 & 0.68 & $\begin{array}{l}\text { Moderately } \\
\text { Relevant }\end{array}$ \\
\hline $\begin{array}{l}\text { Is there any relevance does of any gender policies, } \\
\text { strategies, and/or gender focal points or networks in } \\
\text { your organization? }\end{array}$ & 3.42 & 0.70 & $\begin{array}{l}\text { Moderately } \\
\text { Relevant }\end{array}$ \\
\hline $\begin{array}{l}\text { Is there any relevance about the mainstreaming and } \\
\text { equal representation of women in your organization? }\end{array}$ & 3.41 & 0.69 & $\begin{array}{l}\text { Moderately } \\
\text { Relevant }\end{array}$ \\
\hline $\begin{array}{l}\text { Is there any relevance on what you had received } \\
\text { support from the unit or gender focal point in your } \\
\text { organization for your work on gender such as } \\
\text { mentoring, coaching, detailed assignment, etc.? }\end{array}$ & 3.35 & 0.72 & $\begin{array}{l}\text { Moderately } \\
\text { Relevant }\end{array}$ \\
\hline Subscale & 3.39 & 0.63 & $\begin{array}{l}\text { Moderately } \\
\text { Relevant }\end{array}$ \\
\hline Composite & 3.40 & 0.60 & $\begin{array}{l}\text { Moderately } \\
\text { Relevant }\end{array}$ \\
\hline
\end{tabular}

Legend: $3.50-4.00=$ Very Relevant $; 2.50-3.49=$ Moderately Relevant $; 1.50-2.49=$ Relevant to a Limited

Degree $1.00-1.49=$ Not Relevant 
In terms of operations, the respondents found out all the indicators to be moderately relevant. The indicator on gender being relevant on the mandate of their institutions/organizations got the highest mean of 3.49 ( $\mathrm{SD}=0.67)$. With regards to programmes, all the indicators were likewise observed to be moderately relevant.

Table 5. Gender equality capacity of a university or college administrative council member in terms of skills and processes

\begin{tabular}{|c|c|c|c|}
\hline Indicative Statement & Mean & SD & $\begin{array}{l}\text { Descriptive } \\
\text { Interpretation }\end{array}$ \\
\hline \multicolumn{4}{|l|}{ A. Skills } \\
\hline Gender-responsive monitoring and evaluating & 2.93 & 0.84 & $\begin{array}{l}\text { Moderately } \\
\text { Confident }\end{array}$ \\
\hline $\begin{array}{l}\text { Gender-responsive budgeting and tracking of } \\
\text { resources }\end{array}$ & 2.76 & 0.88 & $\begin{array}{l}\text { Moderately } \\
\text { Confident }\end{array}$ \\
\hline $\begin{array}{l}\text { Gender-responsive planning (e.g. development of } \\
\text { project or programme documents) }\end{array}$ & 2.93 & 0.83 & $\begin{array}{l}\text { Moderately } \\
\text { Confident }\end{array}$ \\
\hline Training/capacity development for gender equality & 2.99 & 0.80 & $\begin{array}{l}\text { Moderately } \\
\text { Confident }\end{array}$ \\
\hline Gender-responsive audit & 2.65 & 0.93 & $\begin{array}{l}\text { Moderately } \\
\text { Confident }\end{array}$ \\
\hline $\begin{array}{l}\text { Gender-sensitive communications (images, } \\
\text { publications, language) }\end{array}$ & 2.93 & 0.84 & $\begin{array}{l}\text { Moderately } \\
\text { Confident }\end{array}$ \\
\hline Subscale & 2.86 & 0.76 & $\begin{array}{l}\text { Moderately } \\
\text { Confident }\end{array}$ \\
\hline \multicolumn{4}{|l|}{ B. Processes } \\
\hline Gender analysis for strategic planning & 2.86 & 0.93 & $\begin{array}{l}\text { Moderately } \\
\text { Confident }\end{array}$ \\
\hline Collection and analysis of sex-disaggregated data & 2.74 & 0.90 & $\begin{array}{l}\text { Moderately } \\
\text { Confident }\end{array}$ \\
\hline $\begin{array}{l}\text { Integration of gender into strategic planning } \\
\text { processes including results statements and indicators }\end{array}$ & 2.92 & 0.86 & $\begin{array}{l}\text { Moderately } \\
\text { Confident }\end{array}$ \\
\hline $\begin{array}{l}\text { Gender-specific programming (e.g. inclusion of } \\
\text { gender in planning documents such as country } \\
\text { programme reports) }\end{array}$ & 2.82 & 0.88 & $\begin{array}{l}\text { Moderately } \\
\text { Confident }\end{array}$ \\
\hline $\begin{array}{l}\text { Inclusion of gender into policies, administrative } \\
\text { instructions, and other directives on finance/ } \\
\text { procurement/IT/ Human Resources/ management } \\
\text { services/security }\end{array}$ & 2.96 & 0.81 & $\begin{array}{l}\text { Moderately } \\
\text { Confident }\end{array}$ \\
\hline $\begin{array}{l}\text { Policies on plans for the equal representation of } \\
\text { women }\end{array}$ & 3.01 & 0.82 & $\begin{array}{l}\text { Moderately } \\
\text { Confident }\end{array}$ \\
\hline Subscale & 2.89 & 0.79 & $\begin{array}{l}\text { Moderately } \\
\text { Confident }\end{array}$ \\
\hline Composite & 2.88 & 0.76 & $\begin{array}{l}\text { Moderately } \\
\text { Confident }\end{array}$ \\
\hline
\end{tabular}

Legend: $\quad 3.50-4.00=$ I am confident enough to lead work on this (Very Confident)

$2.50-3.49=$ I am confident enough to use this to my everyday work (Moderately Confident)

$1.50-2.49=$ I know about this (Familiar)

$1.00-1.49=I$ do not know about this

The gender equality capacity of administrative council members in terms of skill in genderresponsiveness in monitoring and evaluating; budgeting and tracking of resources; planning; audit; training and gender-sensitive communication are perceived moderately confident. Likewise, in terms of processes, the indicative statements are moderately confident. 
Table 6. Association between academic leadership and gender equality capacity of the respondents in terms of training

\begin{tabular}{|c|c|c|c|c|c|c|}
\hline \multirow[t]{3}{*}{ Academic Leadership } & \multicolumn{6}{|c|}{ Gender Equality Capacity (Training) } \\
\hline & \multicolumn{2}{|c|}{$\begin{array}{l}\text { Have you } \\
\text { received an } \\
\text { introductory } \\
\text { training or } \\
\text { orientation on } \\
\text { gender issue }\end{array}$} & \multicolumn{2}{|c|}{$\begin{array}{l}\text { Have you had } \\
\text { taken gender } \\
\text { related training } \\
\text { or courses in the } \\
\text { last two years? }\end{array}$} & \multicolumn{2}{|c|}{$\begin{array}{l}\text { Are you satisfied } \\
\text { with the course/ } \\
\text { training? }\end{array}$} \\
\hline & $\chi^{2}$ & $d f$ & $\chi^{2}$ & $d f$ & $\chi^{2}$ & $d f$ \\
\hline Personal Capability & 1.096 & 1 & .590 & 1 & .054 & 1 \\
\hline Interpersonal Capability & .380 & 2 & .944 & 2 & 1.167 & 2 \\
\hline Cognitive Capability & .847 & 1 & .126 & 1 & .472 & 1 \\
\hline Change-Oriented Capability & 1.429 & 1 & .864 & 1 & .479 & 1 \\
\hline Generic Competency & .669 & 1 & .130 & 1 & 1.809 & 1 \\
\hline Role-Specific & 4.433 & 4 & 4.269 & 4 & 3.995 & 4 \\
\hline Leadership Performance & 5.424 & 2 & 1.838 & 2 & 3.969 & 2 \\
\hline
\end{tabular}

The results in Table 6 revealed that none among the subscales of academic leadership namely: personal capability, interpersonal capability, cognitive capability, change-oriented capability, and generic competency is associated with the gender equality capacity of the respondents in terms of training since all the computed values have $\mathrm{p}>.05$.

Table 7. Relationship between academic leadership and gender equality capacity of the respondents in terms of operations, programmes, skills, and processes

\begin{tabular}{|l|l|l|l|l|}
\hline \multirow{2}{*}{ Academic Leadership } & \multicolumn{4}{l}{ Gender Equality Capacity } \\
\cline { 2 - 5 } & Operations & Programmes & Skills & Processes \\
\hline Personal Capability & .098 & .128 & .128 & .142 \\
\hline Interpersonal Capability & .093 & .114 & .043 & .018 \\
\hline Cognitive Capability & .115 & $.159^{*}$ & .073 & .102 \\
\hline Change-Oriented Capability & .128 & $.183^{*}$ & $.168^{* *}$ & $.166^{*}$ \\
\hline Generic Competency & .072 & .130 & .050 & .051 \\
\hline Role-Specific & $.199^{* *}$ & $.225^{* *}$ & .133 & .094 \\
\hline Leadership Performance & $.209^{* * *}$ & $.209^{* *}$ & $.220^{* *}$ & $.216^{* *}$ \\
\hline
\end{tabular}

***ignificant at $p<.01$

*significant at $p<.05$

$N=153$

It can be gleaned from Table 7 that there is a positive and significant relationship between the following subscales of academic leadership and gender equality capacity: cognitive capability and programmes $(\mathrm{r}=$ $.159 ; \mathrm{p}<.05)$; change - oriented capability and programmes $(\mathrm{r}=.183 ; \mathrm{p}<.05)$, skills $(\mathrm{r}=.168 \mathrm{p}<.05)$, and processes $(\mathrm{r}=.166 ; \mathrm{p}<.05)$; role-specific and programmes $(\mathrm{r}=.225 ; \mathrm{p}<.01)$, and operations $(\mathrm{r}=.199 ; \mathrm{p}<$ .05). Furthermore, it can be observed that leadership performance is positively and highly significantly related to all subscales of gender equality capacity $(r=.209-.220 ; p<.01)$. 
Table 8. Association between administrative creativity and gender equality capacity of the respondents in terms of training

\begin{tabular}{|c|c|c|c|c|c|c|}
\hline & \multicolumn{6}{|c|}{ Gender Equality Capacity (Training) } \\
\hline & \multicolumn{2}{|c|}{$\begin{array}{l}\text { Have you } \\
\text { received an } \\
\text { introductory } \\
\text { training or } \\
\text { orientation on } \\
\text { gender issue }\end{array}$} & \multicolumn{2}{|c|}{$\begin{array}{l}\text { Have you had } \\
\text { taken gender } \\
\text { related training } \\
\text { or courses in the } \\
\text { last two years? }\end{array}$} & \multicolumn{2}{|c|}{$\begin{array}{l}\text { Are you satisfied } \\
\text { with the course/ } \\
\text { training? }\end{array}$} \\
\hline & $\chi^{2}$ & $d f$ & $\chi^{2}$ & $d f$ & $\chi^{2}$ & $d f$ \\
\hline Administrative Creativity & $4.490^{*}$ & 1 & .848 & 1 & .971 & 1 \\
\hline
\end{tabular}

*Significant at $p<.05$

The chi-square test analysis in Table 8 revealed that there is a significant association between respondent's administrative creativity and gender equality in terms of received introductory training or orientation on gender issue $\left(\chi^{2}(1)=4.490 ; \mathrm{p}<.05\right)$.

Table 9. Relationship between administrative creativity and gender equality capacity of the respondents in terms of operations, programmes, skills, and processes

\begin{tabular}{|l|l|l|l|l|}
\hline \multicolumn{3}{|c|}{ Gender Equality Capacity } \\
\hline & Operations & Programmes & Skills & Processes \\
\hline Administrative Creativity & .102 & .115 & $.287^{* * *}$ & $.298^{* * *}$ \\
\hline \multirow{2}{*}{$* *$ significant at $<.01$} \\
$N=153$
\end{tabular}

Table 9 exposed that there is a highly significant relationship between respondent's administrative creativity and gender equality in terms of skills and processes with $r$ values significant at $p<.01$. This implies that the more creative the administrative council members, the more confident in their gender equality capacity in terms of skills and processes.

\section{Discussion}

According to Muda (2016), leaders must have certain personal attributes to be able to perform effectively. These attributes are a mixture of ability and experience, and may require considerable time, effort, and expense to develop. This ability is needed in the practice of leadership principle among subordinates. Leadership is closely related to the ability of a leader to motivate the follower with empowerment and used personality to accomplish vision of the group. Leadership also can be viewed as a phenomenon that requires the process of influencing follower, whereby leaders with good personality and attitude, shares a vision in organization. Some are new to their role and still grasping the knowledge and capacity on how to take their responsibility as a leader in their respective premises. Moreover, all the indicative statements in Table 1 are interpreted as high importance.

In the findings obtained from the study of Mumford et al. (2015), indicated that creative people were more open and less conventional or more autonomous. They were also found to be more driven, more ambitious, more domineering, more hostile and, more impulsive. They are not easy people to lead however, advantageous these characteristics are with respect to subsequent creativity. In addition, leader of creative efforts must themselves be creative people with followers seeking creative input from leaders in initial definition of the problem and in evaluation of the problem solution. As presented in Table 2, innovative and creative ideas have to be introduced by the administrative council members. One potential explanation as to why this syndrome of personality characteristics is so strongly related to creativity may be found in the work of De Dreu, Bass, and Nijstad (2008) as cited in Munford et al. (2015). They argue that as people approach 
creative problems the key issue at hand is not positive or negative affect but rather engaged (e.g., anger) as opposed to disengaged (e.g., shame) affect.

In one state university in the study, they are active in implementing gender related programs based on the numbers of respondents who answered 'yes, they are satisfied with the course/training and those who are not satisfied are from 4 local colleges and university as presented in Table 3. In the study of Paqueo and Orbeta Jr. (2019), they concluded the education institution need to find, design, and implement a win-win mix of interventions, more and better ideas based on analytically sound empirical research is needed. On this score, more studies should be undertaken on the gender gap issue from the lens of the educational development of Filipino males who are currently disadvantaged on average. To make sure, however, that those interventions would lead to desired results, more experimental and quasi-experimental impact evaluation methods should be employed to complement currently available studies, which are mostly qualitative and correlation analyses.

Table 4 data reveals that the leaders adhere to the international convention on gender equality particularly the Discrimination (Employment and Occupation) Convention, 1958 (No. 111) under Article 2 states that each member for which this convention is in force undertakes to declare and pursue a national policy designed to promote, by methods appropriate to national conditions and practice, equality of opportunity and treatment in respect of employment and occupation, with a view to eliminating any discrimination in respect thereof. Furthermore, under Article 3 states that each member for which this Convention is in force undertakes, by methods appropriate to national conditions and practice: (a) to seek the co-operation of employers' and workers' organizations and other appropriate bodies in promoting the acceptance and observance of this policy; (b) to enact such legislation and to promote such educational programmes as may be calculated to secure the acceptance and observance of the policy; (c) to repeal any statutory provisions and modify any administrative instructions or practices which are inconsistent with the policy; (d) to pursue the policy in respect of employment under the direct control of a national authority; (e) to ensure observance of the policy in the activities of vocational guidance, vocational training and placement services under the direction of a national authority; (f) to indicate in its annual reports on the application of the Convention the action taken in pursuance of the policy and the results secured by such action.

According to Stephenson (2018), a gender-responsive budget is a budget that works for everyone (women and men, girls, and boys) by ensuring gender-equitable distribution of resources and by contributing to equal opportunities for all. Gender-responsive budgeting is essential both for gender justice and for fiscal justice. It involves analyzing government budgets for their effect on genders and the norms and roles associated with them. It also involves transforming these budgets to ensure that gender equality commitments are realized. As shown in table 5, gender-responsiveness is not only observed in budget, but also in planning, audit, training and in communication.

As can be gleaned from Table 6, the reason of attending such orientation/trainings could be based on the Philippine Commission on Women Memorandum Circular No. 2011-01 in order to heighten the level of awareness and appreciation of the employees regarding the gender and development, they need to facilitate programs and related activities in order to abide on this memo. Besides academic institutions are considered part of the guidelines and procedures for the establishment, strengthening, and institutionalization of the GAD Focal Point System (GFPS) in constitutional bodies, government departments, agencies, bureaus, SUCs, GOCCs and all other government instrumentalities; and to clarify the roles and responsibilities, composition and structure of the GFPS to enable it to function as a mechanism for catalyzing and accelerating gender mainstreaming in the agency towards the promotion of Gender Equality and Women's Empowerment.

The findings in Table 7 implied that that cognitive capability and programmes of gender and development are related at some point in which leaders are capable of executing programs effectively related to Gender and Development (GAD) and on how they incorporate these programs to the mandates of their respective schools. Based on the conclusions of findings of the study of Chen Guoquan \& Zhou Wei (2009) that the three kinds of leadership behavior of TRC model have significant effect on the organizational learning 
capability, in which the most important is change-oriented, the second is relation-oriented, and the third is task-oriented according to the significant findings. Organizational learning capability has a complete mediate effect on the relationship between relation-oriented, change-oriented leadership behavior and organizational performance. According to the research of Ibarra, Ely, and Kolb (2013), there is a need to consider performance feedback, which is necessary for growth and advancement but full of trip wires for women. In many organizations 360-degree feedback is a basic tool for deepening self-knowledge and increasing awareness of one's impact on others - skills that are part and parcel of leadership development.

As shown in Table 8, these knowledge and skills are incurred from trainings provided by the GAD Focal point by enhancing their capability to perform their tasks efficiently. As stipulated in the Magna Carta of Women (Republic Act No. 9710) which defines Gender and Development Program (GAD) as the development perspective and process that is participatory and empowering, equitable, sustainable, free from violence, respectful of human rights, supportive of self-determination and actualization of human potentials. It seeks to achieve gender equality as a fundamental value that should be reflected in development choices and contends that women are active agents of development, not just passive recipients of development. GAD focuses on Gender Mainstreaming or a strategy for: making women's as well as men's concerns and experiences an integral dimension of the design, implementation, monitoring, and evaluation of policies, programs and projects in all social, political, civil, and economic spheres so that women and men benefit equally; and assessing the implications for women and men of any planned action, including legislation, policies or programs in all areas and at all levels. As defined by UN Women, gender equality training is a 'tool, strategy, and means to effect individual and collective transformation towards gender equality through consciousness raising, empowering learning, knowledge building, and skill development'. Gender equality training is not a goal in itself, or a single tool to implement gender mainstreaming. It is part of a wider set of tools, instruments, and strategies. Gender equality training should be incorporated into a continuous and long-term process. As shown in Table 8, a positive and high significant relationship was found between the administrative creativity and skills $(r=.287 ; \mathrm{p}<.01)$. and processes $(r=.298 ; \mathrm{p}<.01)$ dimensions of gender equality capacity. These findings indicate that the respondents are confident with great extent of performing their jobs as administrative officer in their respective institutions because they are moderately confident which means that they are confident enough to do their job in their everyday wok. Because through trainings under the gender and development programs helped them enhance their gender capacity to be responsive in planning, monitoring and evaluating their work outputs, also they are gender-sensitive in the process of communications that made them creative on how they deliver their services to the stakeholders. They are also creative in strategic planning that they could create new ideas, innovations, and new ways of performing tasks.

The results in Table 9 imply that these knowledge and skills are incurred from trainings provided by the GAD Focal point by enhancing their capability to perform their tasks efficiently. As stipulated in the Magna Carta of Women (Republic Act No. 9710) which defines Gender and Development Program (GAD) as the development perspective and process that is participatory and empowering, equitable, sustainable, free from violence, respectful of human rights, supportive of self-determination and actualization of human potentials. GAD focuses on Gender Mainstreaming or a strategy for: making women's as well as men's concerns and experiences an integral dimension of the design, implementation, monitoring, and evaluation of policies, programs and projects in all social, political, civil, and economic spheres so that women and men benefit equally; and assessing the implications for women and men of any planned action, including legislation, policies or programs in all areas and at all levels.

As defined by UN Women, gender equality training is a 'tool, strategy, and means to effect individual and collective transformation towards gender equality through consciousness raising, empowering learning, knowledge building, and skill development'. Gender equality training is not a goal in itself, or a single tool to implement gender mainstreaming. It is part of a wider set of tools, instruments, and strategies. Gender equality training should be incorporated into a continuous and long-term process.

\section{Conclusion}


Based on the findings of the study there is no significant association or relationship between the academic leadership capability and gender equality capacity in terms of an introductory training or orientation received on gender issue, gender related training or courses taken in the last two years, and satisfied with the course/training. But in terms of operations, programmes, skills, and processes there is a positive and significant relationship between academic leadership capabilities and gender equality capacity; furthermore, it is also observed that leadership performance is positively and highly significantly related to all subscales of gender.

There is a significant association between respondent's administrative creativity and gender equality capacity in terms of introductory training or orientation on gender issue and a positive and high significant relationship between administrative creativity and skills and processes and significant relationship in terms of operations and programmes. Hence, the local colleges and university need to conduct seminars and trainings to enhance the awareness of the officials and other constituents on gender sensitivity, and the administrators of local colleges and university may come up with a comprehensive gender equality program to be included in their strategic planning to sustain the efficacy of its operation and programs.

\section{References}

1. Ancona, Deborah \& Bresman, Henrik (2018). The Five Key Capabilities of Effective Leadership. November 14, 2018. https://knowledge.insead. edu/leadership-organisations/the-five-keycapabilities-of-effective-leaders hip-10441.

2. Anderlini, S. (March 8, 2015). "Expansion or Contraction? Women's Rights in the MENA Region in 2015". Wilson Center, published, 8 March 2015. https://icanpeacework.org/2015/03/06/anderlinicomments-on-womens-rights-trends-in-2015/

3. Baxter, J. \& Hewitt, B. (2013). Negotiating Domestic Labor: Women's Earnings and Housework Time in Australia. Feminist Economics, 2013, vol. 19, issue 1, 29-53. https://econpapers.repec.org/scripts/redir.pf?u=http\%3A\%2F\%2Fhdl.handle.net\%2F10.1080\%2F135 45701.2012.744138;h=repec:taf:femeco:v:19:y:2013:i:1:p:29-53

4. Beneria, L., Berik, G., \& Floro, M. (2016). Gender, Development and Globalization Economics as if All People Mattered. https://www.routledge.com/Gender-Development-and-GlobalizationEconomics-as-if-All-People-Mattered/Beneria-Berik-Floro/p/book/9780415537490

5. De Dreu, C.K.W., Baas, M., \& Nijstad, B.A. (2008). Hedonic tone and activation level in the moodcreativity link: Toward a dual pathway to creativity model. Attitudes and Social Cognition, 94, 739756.

6. Eliadis, Andriana (May 31, 2018). Women and Leadership in Higher Education. Fielding Graduate University Leadership of Higher Education Systems

7. file:///C:/Users/ASUS/Downloads/WomenandleadershipinHigherEducation-Eliadis.pdf

8. European Scientific Journal February 2018 edition Vol.14, No.4 ISSN: 1857 - 7881 (Print) e - ISSN 1857- 7431 147).

9. European Institute for Gender Equality https://eige.europa.eu/gender-mainstrea ming /concepts-anddefinitions

10. Gakiya, M., Wu, A.T., \& Al-Rousan, T. (2016). Women's Leadership and Empowerment for Peacebuilding. Sasakawa Peace Foundation.

11. https://www.spf.org/publication/upload/Women\%27s\%20Leadership\%20and\%20Empowerment $\% 20$ for\%20Peacebuilding.pdf

12. Gender Equality Capacity Assessment Tool. https://www.unwomen.org/en/digitallibrary/publications/2014/6/gender-equality-capacity-assessment-tool\#view

13. Guoquan, C. \& Wei, Z. (2009). A study on the relationship among CEOs' leadership behavior, organizational learning capability, and organizational performance [J]. Science Research Management. https://www.cnki.com.cn/cnki/images/newversion/logo.jpg?v=200717

14. Ibarra, Herminia, Ely, Robin J., \& Kolb, Deborah M. (Sept, 2013). Women Rising: The Unseen Barriers. Harvard business review, 2013 - westlanglit.boun.edu.tr http://westlanglit.boun.edu.tr/wpcontent/uploads/ 2020/01/RR37_1-Women-Rising_The-Unseen-Barriers. Pdf 
15. Ibtisam Khalid Yahia Salama (2018). The Relationship Between Organizational Culture and Administrative Creativity in Universities. European Scientific Journal February 2018 edition Vol.14, No.4 ISSN: 1857 - 7881 (Print) e - ISSN 1857- 7431146 Doi: 10.19044/esj.2018. v14n4p146 URL:http://dx.doi.org/10.19044 /esj.2018.

16. Jacqueline, M., \& Rungrojngarmcharoen, K. (2014). A Study of Academic Leadership Capabilities of Teachers in a Selected No. 2 Basic Education High School in Myanmar. https://www.semanticscholar.org/paper/A-Study-of-Academic-Leadership-Capabilities-of-in-aJacqueline-Rungrojngarmcharoen/4b2889a804daf04ec316a6e77aecd099b0f6e58f

17. Memorandum Circular No. 2011-01: Guidelines for the creation, Strengthening, and Institutionalization of the GAD Focal Point System. https://pcw.gov.ph/memorandum-circular-no2011-01-guidelines-for-the-creation-strengthening-and-institutionalization-of-the-gad-focal-pointsystem/

18. Muda, Wan Hanim Nadrah Binti (2016). Developing a Leadership Capability for Team Leaders' in the Construction Industry: A Concept for Organizational Success. Journal of Vocational Education and Training. SP-10. Vol. 8. Published: 2016/10/06.

19. Mumford, Michael, Medeiros, Kelsey, Steele, Logan, \& Watts, Logan (2015). Leadership, Creativity, and Innovation: An Overview. CHAP. Published: 2015/01/01.

20. Paqueo, Vicente B. \& Orbeta, Aniceto Jr. C. (2019). Gender Equity in Education: Helping the Boys Catch Up. Philippine Institute for Development Studies. Https://Pidswebs.Pids.Gov.Ph/CDN/PUBLICATIONS/Pidsdps1901.Pdf

21. Philippine Commission on Women. https://pcw.gov.ph/republic-act-9710-magna-carta-of-women/

22. Rodrigues, António, P., Gonçalves, A., Marques, H. C., \& Diniz, F. (2013). Gender equality in institutions of higher education: Diagnosis and action plan for an institution of higher education in the north of Portugal. International Journal of Teaching and Education, 1(1), 18-51.

23. Salama, Ibtisam Khalid Yahia (2018). The Relationship Between Organizational Culture and Administrative Creativity in Universities. European Scientific Journal February 2018 edition Vol.14, No.4 ISSN: 1857 - 7881 (Print) e - ISSN 1857- 7431 146, Doi: 10.19044/esj.2018.v14n4p146 URL:http://dx.doi.org/10.19044/esj.2018.v14n4p146

24. Scott, G., Coates, H. \& Anderson, M. (2008). Learning leaders in times of change: Academic leadership capabilities for Australian higher education. Sydney: Australian Learning \& Teaching Council. https://research.acer.edu.au/cgi/viewcontent.cgi?article=1001\&context=higher_education

25. Sevilla-Sanz, A., Gimenez-Nadal, J.I. \& Fernández, C. (Dec. 2010). Gender Roles and the Division of Unpaid Work in Spanish Households. Pages 137-184 | Published online: 22 Dec 2010. https://doi.org/10.1080/13545701.2010.531197

26. Stephenson, Mary-Ann (2018). A Guide to Gender-Responsive Budgeting. Type Guidelines and toolkits. Publication date 28 Feb 2018. https://policy-practice.oxfam.org.uk/publications/a-guide-togender-responsive-budgetin g-620429

27. United Nations Entity for Gender Equality and the Empowerment of Women (UN Women), 2014). UN Women Training Centre. URL - https://www.unwomen.org/en/digitallibrary/publications/2014/6/gender-equality-capacity-assessment-tool

28. Wu, Ruohan and Cheng, Xueyu (2016). Gender equality in the workplace: The effect of gender equality on productivity growth among the Chilean manufacturers. The Journal of Developing Areas. 50. 257-274. 10.1353/jda.2016.0001. https://www.ncbi.nlm.nih.gov/pmc/articles/PMC45 84998/ 